\title{
Comparison of Land Law Systems: A Study on Compensation Arrangements and Reappraisal of Land Acquisition for Public Interest between Indonesia and Malaysia
}

\author{
Embun Sari ${ }^{\star}$, Muhammad Yamin, Hasim Purba and Rosnidar Sembiring
}

Faculty of Law, Universitas Sumatera Utara, Medan City, Universitas Street No. 19 Padang Bulan, Medan City, 20155, Indonesia

\begin{abstract}
Land is a livelihood land for everyone to achieve prosperity in various fields; besides that, the land is also the essential capital in the development of a nation, and its benefits must be exploited as well as possible. There are still many lands affected by the procurement of development for the public interest that are detrimental to the community, including compensation and land that an appraisal has not appraised. This research method uses normative juridical research with the approach of laws and concepts and collects primary legal materials in existing regulations in both countries. Data collection techniques consist of literature study, observation, interviews, and use of questionnaires. The results of this study found that both Indonesia and Malaysia regulate compensation arrangements in the Act. Although both of them depart from different legal systems, where Indonesia is subject to the civil law system and Malaysia is subject to the common law system, both have the same. In Indonesia, it has not explicitly regulated reappraisal in its law, in the future, it is necessary to consider the pattern of reappraisal carried out by Malaysia, because this pattern according to the author, with the current legal vacuum, it is necessary to have a fast track process to provide justice and legal certainty.
\end{abstract}

Keywords: Comparative Law, Land, Compensation, Reappraisal, Land Acquisition, Indonesia, Malaysia.

\section{INTRODUCTION}

Law Number 5 of 1960 concerning Basic Agrarian Principles has played an essential role in the life of land law in Indonesia where there has been a change from the old Indonesian land law system based on western law and customary law or known as pluralistic, which has now become the legal system which refers to the 1945 Constitution and Pancasila as the ground norm for the Indonesian legal system. Thus, the spirit and content of the law reflect the face of Indonesia in the land system.

The basis for the existence of Law Number 5 of 1960 concerning the Basic Agrarian Principles are: first; that in the Republic of Indonesia, where the structure of the life of the people, including the economy, is mainly agrarian, earth, water, and space as gifts from God Almighty have an essential function to build a just and prosperous society, second; that the agrarian law in effect before Law Number 5 of 1960 concerning Basic Agrarian Principles was partly composed based on the aims and principles of the colonial government and partly influenced by it so that it is contrary to the interests of the people and the state in completing the current national revolution. As well as the development of the universe, third; that before the enactment of Law Number 5 of 1960 concerning Basic

*Address correspondence to this author at the Faculty of Law, Universitas Sumatera Utara, Medan City, Universitas Street No. 19 Padang Bulan, Medan City, 20155, Indonesia; E-mail: embunsari25@yahoo.com
Agrarian Laws, agrarian law is dualistic, with the enactment of customary law in addition to the necessity of western law, and fourth; that for the indigenous people of Indonesia colonial agrarian law did not guarantee legal certainty (Sari, 2017).

In addition to other laws that have previously existed for that, if there are new laws and regulations, it is expected that the related parties are careful to avoid conflicting regulations and eliminate one another but are expected to support and even be able to expedite and clarify the existing rules. There is. As referred to in Law Number 5 of 1960 concerning Basic Agrarian Principles, land rights are rights to the surface of the earth which are supported by technological advances that use underground space or building space above the land. Land rights, which are rights to the earth's surface, are a limited unit and a two-dimensional unit consisting of a length and width known as the community's land area (Siregar \& Koto, 2015).

In some agricultural countries, the land is a land of livelihood for everyone to achieve prosperity in various fields; besides that, the land is also the essential capital in the development of a nation, and its benefits must be exploited as well as possible (Mulyadi, 2017). The relationship between people and the land they own, causing the process of taking over people's land without an element of "willingness" from the right holders, will cause many problems. Land acquisition, revocation of rights, or whatever the name always involves two dimensions that must be placed in a 
balanced manner, namely the interests of the "government" and the interests of "the community". The two parties involved, namely the "rulers" and "the people," must both pay attention to and obey the applicable provisions regarding land acquisition. Moreover, if these provisions are not heeded, problems will arise that can lead to disputes (Mulyadi, 2017).

According to Jean Jacques Rousseau and $M$. Kaser, and P.B.J. Wubbe (1990) stated that the land's owners were transferred based on community agreements incarnated by law. In-state life, all assets in the state are public property controlled by state law. This also applies to every state's legal relationship to have legal authority over the state's property. Thus, ownership of land by the state contains the following categories: First, the state does not own land, but in particular, has a relationship with the land, especially those related to public interests. Second, the state is the sole owner of the land both in the complete sense and in the sense of owning it. Third, the state owns land besides being owned by individuals. Fourth, the state exercises power over land owned by the community as if it belonged to it (Fitri, 2018).

In the future, land issues also need to be seen as part of the climate of globalization, in which economic globalization has broad implications in the field of law, one of which is land. As referred to at the next level, legal globalization will result in the prevailing regulations in developing countries closer to or oriented towards developed countries (convergence). However, there is no guarantee that these regulations will produce the same results in every country. This legal globalization can be seen from the development of individual ownership marked by land certification and land acquisition. This proves that the provisions of Indonesian land law (agrarian) are trying to welcome the era of globalization $(\mathrm{H}, 2019)$.

One of the impacts of globalization is related to the legal certainty of compensation for land in the Land Acquisition for the Bener Dam in Purworejo and Wonosobo Districts. As referred to at the next level, legal globalization will result in the prevailing regulations in developing countries closer to or oriented towards developed countries (convergence). However, there is no guarantee that these regulations will produce the same results in every country. When the Compensation Money is to be paid from the 181 fields that have been declared eligible by the Financial and Development Supervisory Agency, only four fields are willing to receive the payment. This is because the community feels that the price set in 2018 paid in December 1999 is not by the conditions. Many one fields filed a lawsuit to the Purworejo District Court and have received an "inkracht" decision from the Supreme Court of the Republic of Indonesia by Decree No. The people of the Republic of Indonesia and the Ministry of Agrarian Affairs and Spatial Planning or National Land Agency) thus justifying the Purworejo District Court's Decision which in essence stated that the existence of buildings, complementary facilities, and non-physical values was not assessed by the Public Appraisal Service Office Sih Wiryadi and Partners, thus granting a lawsuit from the plaintiff by giving compensation to be Rp. 76,735,938.00; (There was an increase of around Rp. 50,000,000, - or an increase of about three times. Seeing this, other people also filed a lawsuit.

On the other hand, both in Law Number 2 of 2012, Government Regulation no. 19 of 2021 concerning the Implementation of Land Acquisition for Development for Public Interest, and Presidential Regulation No. 71 of 2021 concerning the Implementation of Land Acquisition for Development for Public Interest does not regulate reappraisal, where the value is the value at the time of the announcement of the location determination. This opens up space for discrimination and legal uncertainty in the land. In the Bener Dam case, the value set in 2018 is already deficient compared to current conditions. The life of the compensation received will likely be worse than before because the value received even to buy replacement land as large as the previously owned land is not sufficient, not to mention overcoming other losses needed to continue their life in a new place.

Empirical research conducted in many countries shows that the amount of compensation provided to affected landowners is often insufficient to rebuild their livelihoods after expropriation. Banerjee and Van Eerd found that, in Cambodia, Indonesia, Nigeria, Sri Lanka, and the Philippines, compensation and resettlement assistance provided to affected populations was insufficient to cover their losses, enable them to purchase alternative land and maintain a standard of living. After their land was expropriated. In China, a survey of 476 takeover cases conducted by Keliang and others revealed that $65.5 \%$ of the affected farmers were dissatisfied with the compensation provided (Tagliarino, 2017).

In addition, there are also countries in mainland ASIA, namely Malaysia, where these countries have similarities from a cultural aspect to Indonesia, even 
though the legal system is different. The concept of land acquisition was developed in Malaysia, where previously most of the fields (usually owned by rich people) were taken under the 1960 Land Acquisition Deed to build or provide facilities to the public (mostly poor people) people's land is reversed. The poor are taken to be distributed to the rich or to private companies to be used commercially. In Malaysia, with the changes in section 3 (b) of the 1960 Land Acquisition Deed on September 12, 1991, there was a change in the concept of land acquisition (Zakie, 2011). Section 3 (b) The Land Acquisition Deed authorizes the State's Authority to take land for any purpose which in the opinion of the State's Authority is beneficial for the economic development of the state or the ordinary people or the familiar people whether that purpose is carried out or carried out by everyone (including individuals) or by an agency. It does not matter, as long as it is beneficial for economic development, the state or the public whether such purpose will provide or become a benefit in respect of it, it depends on the opinion of the Ruling State Party (Zakie, 2011).

As for some of the same studies that have conducted previous research, including:

First, research conducted by Basyirah Mustarin with the title compensation for land acquisition for the public interest explains that the city government provides compensation for the location of the land that will be affected by the construction of these public facilities. The mechanism for land acquisition or land acquisition in cities is carried out by providing compensation for the value of the land price to be acquired appropriately and fairly based on Article 9 paragraph (2) of Law Number 2 of 2012. Land issues have been highly relevant and considered in depth. This is related to the land sector's policies because of the level of policy implementation shown so far (Mustarin, 2020).

Second, the research conducted by Hairul Maksum with the title implementation of compensation for land acquisition for the expansion of the Masbagik public market in East Lombok Regency in a review of Law Number 2 of 2012 explains that in determining the form of compensation for the expansion of the masbagik public market carried out based on Article 1 point 10 Law Number 2 of 2012. Article 37 of Law No.2 / 2012 states that the land agency shall conduct deliberations with the entitled parties within 30 (thirty) working days from the time the results of the assessment are submitted to the land agency. to determine the form and amount of compensation based on the results of the assessment of compensation, the results of the agreement in deliberation become the basis for the provision of compensation to entitled parties which is included in the minutes of agreement (Maksum, 2016).

Third, M. Arul Vikram and K. Murali's research, with the title a critical review on land acquisition and valuation process across the world, explains that Land acquisition was a challenging factor in India for project development. The process and techniques adopted in various countries are reviewed in this paper. It was observed that no single best practice exits for land acquisition are available. This can be accomplished by taking up research initiatives on valuation studies in Universities for the valuers and supporting experts (Vikram \& Murali, 2016).

Fourth, Subash Ghimire's research, Arbind Tuladhar and Sagar Raj Sharma, with the title governance in land acquisition and compensation for infrastructure development, explains that The study reveals that the different countries have different laws and regulations procedures for land acquisition and land valuation approaches. They depend upon the social, political, and economic conditions of the country. The major gap identified from the study about Nepal's situation is the implementation of land acquisition, compensation, and land valuation system about good governance principles, namely public participation, access to information, transparent procedure, and stakeholder's interaction (Ghimire, Tuladhar, \& Sharma, 2017).

Based on the explanation above, it is necessary to further discuss these issues in order to find new formulations in order to solve problems that arise in the existing land law system, especially about compensation and re-assessment (reappraisal) that occurs due to errors of the organizers and the lack of rules provide legal certainty and justice to communities whose lands are affected by development for the public interest. Therefore, the author needs to examine the land law system in Indonesia, compensation and reappraisal of land acquisition for the public interest in Indonesia, and a comparison of compensation and reappraisal of land acquisition for the public interest between Indonesia and Malaysia.

\section{METHODS}

This study using normative juridical research. The definition of normative juridical is a type of research that emphasizes more on library research, where the materials used will be obtained from laws, literature, 
mass media, which are related to writing materials. Besides the data obtained from the literature, the authors will also be described in this study's results. After obtaining the data using juridical normative, the authors describe in words in the study entitled Comparison of the Land Law System: a study of compensation arrangements and land acquisition reappraisals for the public interest between Indonesia and Malaysia (Simaremare \& Noho, 2021).

The analytical method used refers to laws, existing regulations, looks at existing legal principles and concepts, compares land acquisition arrangements related to compensation and reappraisal, and then traces future efforts to reform land acquisition laws. Normative juridical research is needed because it is necessary to make an inventory of positive law, discover the principles and basic philosophy (dogma or doctrine) of positive law, and in-concreto legal findings feasible be applied to resolve specific legal cases (Noho, 2019).

How to collect data used in a study depends on the scope and objectives of the study. According to Ronny Hanitijo Soemitro (1990), data collection techniques consist of literature study, observation, interviews, and use of questionnaires. Based on the scope, objectives, and approach in this study, the data collection technique used is a literature study of the secondary data analyzed. The secondary data obtained will be used to support the analysis in this study.

\section{RESULTS AND DISCUSSION}

\section{Land Law System in Indonesia}

Indonesia is an ex-Dutch colony, so it cannot be denied that the Dutch heavily influences the legal system. The Netherlands is also a country that adheres to a civil law system and puts forward written rules as a benchmark for the law's operation. One of these rules is regarding land, in which the land law system, in terms of the choice of objectives and legal principles used as a guideline for realizing the objectives, has been stipulated in Law Number 5 of 1960 concerning Basic Agrarian Principles. On the one hand, Law Number 5 of 1960 concerning Basic Agrarian Regulations serves as the elaboration of the objectives and legal principles of Article 33 paragraph (3) of the 1945 Constitution of the Republic of Indonesia, but on the other hand, Law Number 5 of the Year 1960 concerning the Basic Regulations for Agrarian Principles and legal principles which serve as a source for the development of policies and laws and regulations on national land. The direction is to ensure the realization of prosperity for all Indonesian people.

Article 2 paragraph (1) of Law Number 5 of 1960 concerning Basic Agrarian Principles, that the earth, water, and space, including the natural resources contained therein, are at the highest level "controlled" by the state as an entire organization. The state's right to control is meant to give authority to legal institutions and concrete legal relations between the state and Indonesian land. The state's authority is the delegation of the nation's duties so that the authority is solely public. The state, in this case, is not a legal entity that owns. However, the state is given the authority to regulate as stated in Article 2 paragraph (2) of Law Number 5 of 1960 concerning Basic Agrarian Principles (Hamler, 2018): 1. regulating and administering allotment, use, supply, and maintenance of the earth, water, and space; 2 . determine and regulate the legal relations between people and the earth, water, and space and; 3. regulate and determine the legal relationship between people and legal actions concerning the earth, water, and space.

Based on this authority, the state is obliged to regulate the provision, allocation, and use of earth, water and space as well as possible by considering the principles of justice, certainty and benefit. The land is one of the natural resources whose amount is relatively fixed and unlikely to increase, so regulation and control in land use (land) are needed so that changes in land use can be controlled, especially in changes in use with a land-use change that can have a detrimental impact on the community (Hamler, 2018).

\section{Compensation and Reappraisal of Land Acquisition for Public Interest in Indonesia}

In essence, land acquisition is the government's actions to acquire land for the public interest, pursued based on deliberation to reach an agreement regarding the release of rights and compensation before the revocation of rights occurs. The results of this deliberation then form the basis for the payment of compensation. Principles or principles in the legal context of the land acquisition include (Subekti, 2016): 1. control of land and use of land by anyone and for any purpose, there must be a basis of rights; 2 . all land rights, directly or indirectly, derive from the rights of the nation; 3. methods of obtaining land that a person or legal entity has already held must be through an agreement between the parties concerned; 4 . in a state 
of coercion, if the deliberation process cannot result in an agreement, for the public interest, the authority (in this case the president) is authorized by law to take the necessary land by force, without the consent of the owner of the land, through a program of revocation of rights; 5 . Either in the process of acquiring land based on an agreement or in the event of revocation of rights, the party who has surrendered the land must be given an appropriate compensation, in the form of money, facilities, or another land as a substitute and; 5. People who are asked to surrender their land for development projects have the right to receive protection from the Civil Service Officials or the Village Civil Service. In a state of force, it means that the other route has failed, then the president has the authority to revoke rights without the consent of the right subject according to Law Number 20 of 1961.

The basis for land acquisition for the public interest is Article 10 letter c of Law Number 2 of 2012, which states that land for public purposes also includes reservoirs, dams, weirs, irrigation, drinking water channels, sewerage, sanitation, and irrigation buildings (Kusumarini, Silviana, \& Triyono, 2016). Furthermore, these types of public interests were expanded in Law Number 11 of 2020 concerning Job Creation Chapter VIII.

Land that is needed and desired for the revocation of land rights and land acquisition for development purposes carried out by the government, so in this case, a guarantee is needed, both for the citizens and the government. In terms of filling in this sustainable development, the government needs land so that in order to obtain the land, the government inevitably has to revoke land rights and release land rights for the people who own the land, so that the land becomes government property and can be used for development for the sake of its public interest (Kumalasari \& Sudiarta, 2020). Article 1 point 10 of Law Number 2 the Year 2012 states that "Compensation is a fair and fair compensation to those entitled to in the land acquisition process (Hamdi, 2014)."

Article 36 Compensation can be given in the form of 1. money; 2. replacement land; 3 . resettlement; 4 . share ownership; or any other form agreed upon by both parties. Elucidation of Article 36 letter $c$ What is meant by "resettlement" is the process of providing replacement land to the Entitled Party to another location by the agreement in the Land Acquisition process. Letter $d$ What is meant by "form of compensation through share ownership" is the participation of shares in development activities for the related public interest or its management based on an agreement between the parties. Letter (e): Other forms agreed by both parties, for example, a combination of two or more forms of Compensation as referred to in letter a, letter b, letter c, and letter d (Tuna, 2014).

Article 31 paragraph (1) and (2) Law Number 2 of 2012 states that the Land Agency determines the Appraiser by the provisions of the statutory regulations, and the Land Institution announces the appointed Appraiser as referred to in paragraph (1) to assess the Object of Procurement. Soil. Elucidation of Article 31 paragraph (1) The statutory provisions in question are provisions concerning government agencies' procurement of goods or services. Article 32 paragraph: 1. The Appraiser appointed as referred to in Article 31 paragraph (1) must be responsible for the assessment carried out, and 2. Violation of the Appraiser's obligation as referred to in paragraph (1) shall be subject to administrative or criminal sanctions by the statutory regulations' provisions (Tuna, 2014).

Article 33 The Appraiser of the value of compensation as referred to in Article 32 paragraph (1) shall be evaluated per plot of land, covering: 1 . land; 2 . space above ground and underground; 3 . buildings; 4 . plants; 5 . objects related to land; or 6 . other assessable losses. Elucidation of Article 33 letter $\mathrm{f}$ : What is meant by "other losses that can be assessed" are nonphysical losses which can be equated with money value, for example, losses due to loss of business or work, cost of relocation, cost of transfer of profession, and value of the residual property (Tuna, 2014).

The authorization for appraisal, in this case, is represented by the Public Appraisal Service Office to conduct an appraisal of the object that will be subject to compensation. These assessment results are final, meaning that the government or agency requiring community-owned land pays according to the assessment results and closes the deliberation space regarding the size and amount, limited to deliberation on the form of compensation. The presence of appraisals as an institution that conducts assessments is considered more professional and objective in determining compensation by the considerations of Law Number 2 of 2012.

According to Ray M. Northam in Sulasi Rongiyati (2012), two definitions of land value are 1. Land value is the market value, namely the buying and selling price of land at a specific time and; 2 . Land value is the 
assessment value, namely the value estimated by an appraiser. Market value is essential data for the assessed value.

The implementation of the appraisal must be accompanied by provisions that regulate: 1 . The value of compensation should be determined from the value when the announcement of the Decision on Determination of Location; 2 . The compensation value is a single value per plot of land and; 3 . The determination of the compensation value must be objective because it is the basis for conducting deliberations on compensation (Suntoro, 2019).

\section{Comparison of Compensation Arrangements and Reappraisal of Land Acquisition for Public Interest between Indonesia and Malaysia}

The term "comparative law" (not "comparative law") itself is precise that comparative law is not a law such as civil law, criminal law, constitutional law, and so on, but is an activity to compare one legal system with another legal system (Soekanto, 1989). The comparative law approach is based on two understandings that are so concise that they are never said. The first is that law, as understood in Barata, is a harbinger of civilization. The second understanding is that of civilization which is primarily European (extended to America, due to emigration and previous European settlement). In the early twentieth century, civilization was viewed primarily as Western, white, and Christian (Menski, 2015).

Comparative law includes improvements to international law: It is helpful in historical and philosophical legal research; It is essential to understand better and to correct one's national laws and; It helps us, enhances understanding of strangers, and contributes to creating a favorable context for the development of international relations (Menski, 2015).

Starting from the explanation above, the existence of land acquisition legal arrangements relating to compensation and reappraisal also needs to be reviewed in legal comparisons between Indonesia and Malaysia. This is to understand better and develop land law in Indonesia, develop an understanding of other nations, and contribute to creating a good relationship or atmosphere for the development of international relations and legal harmonization in the formation of supranational law.

It should be noted together that Indonesia and Malaysia depart from two different systems. Indonesia adheres to the civil law system, and Malaysia adheres to the common law system. In civil law systems, the law is binding because the law is systematically codified. Thus, the continental European system emphasizes the importance of written law, namely statutory regulations, as the primary basis for its legal system (Hadi, 2016). Meanwhile, the common law system of law created by courts or judges through their decisions is a primary law source. Joseph Dainow stated that a court or judge's decision is not only binding on the parties in a case, but the decision must be followed by another judge afterwards in the same case; therefore, the decision becomes a general rule or customary rule (Dainow, 1967).

Kamba in Peter De Cruz (2017) says that there are three stages involved in the comparison process; 1. Descriptive phrase: taking a description of the norms, concepts, and institutions of the related system; 2 . Identification phase: the differences and similarities of the systems being compared and; 3. Explanation phase: a stage where an attempt will explain the similarities and inequalities between systems, concepts, or institutions.

In addition, there are also countries in mainland ASIA, namely Malaysia, where these countries have similarities from a cultural aspect to Indonesia, even though the legal system is different. In Malaysia, the rules for land acquisition for public purposes are regulated in Act 486, Land Acquisition Act 1960 As of 1 January 2015 (LAA), which has a dual purpose, first to provide a standard method of procedure applicable to all states in Malaysia and second to serve as a quick mechanism to acquire compulsory land where they are indispensable for development purposes. If properly implemented, the law should provide justice to deprived owners and other affected parties and fulfill the objective of providing appropriate development and infrastructure to the public (Mohamad, Sufian, \& et al., 2013).

Stages The land acquisition process involves submitting a valid Form provided in LAA Malaysia; 1. Notification that land will be acquired shall be published in the State Gazette; 2. Note that land must be entered and surveyed; 3 . Preparation of plans and lists of land to be acquired; 4. Declaration of the intended acquisition of the scheduled land; 5 . Notification of questions for interested people; 6. Notification to interested persons to request written evidence; 7 . Investigations before the Land Administrator; 8. Written Compensation Award by Land Administrator; 9. Written 
Reward Service of Compensation by Land Administrator to interested persons; 10 . Notification to take ownership in urgent cases before compensation payment is given by issuing a "Certificate of Urgency"; 11. Notification to occupants or owners to vacate the building erected on the acquired land; 12 . Note that ownership has been taken from the acquired land; 13. Notification to request the submission of documents on the land rights that have been acquired; 14. Interested persons have six weeks from the date of grant of the Land Administration to consider whether to object to the provision of adequate compensation; 15 . The Land Administrator can raise any questions to the court to be determined; 16. Interested persons may refuse compensation and submit the objection to the court, and; The Land Administrator will refer the objections received to the High Court.

About compensation not defined in the land acquisition law. The condition derives its meaning from the stipulation where the amount of money must be paid by the owner who is confiscated because of the loss of his land. The amount payable can represent the amount not only for land taken but also for other losses suffered from the acquisition. The basic principle is to place the affected landowners in the same position, after the acquisition as before, no worse or better. This is also called the principle of equality (Alias \& Daud, 2015).

The general rule is that the compensation measure should be based on the market value of the land acquired. Market value is "the price a willing buyer will pay to a willing seller in a situation where fair business principles drive both parties, and there is no reluctance on the part of the vendor to sell, and no one, an urgent need, forces the buyer to buy." When assessing the land's market value to be acquired, it is necessary to consider: 1. The size, shape, condition, and location of the land; 2 . Land use; 3 . land development potential (if any); and market conditions at the valuation material's date.

The material date for assessing the land's market value to be legally acquired is the date of issuance of the Declaration under Section 8 (1) LAA in the State Gazette that the land will be legally acquired. Where only a portion of the land is acquired, Paragraph 2 (d) of the First Schedule of LAA 1960 provides for compensation to be paid for "damage, if any, sustained or likely to be sustained by an interested person (owner or occupant) when the Land Administrator takes ownership of the land. Because of an acquisition which adversely affects his other property, whether movable or immovable, (including remaining land) in any other way ". This may include lost revenue by the business, reduced utility gained from using remaining property, and so on.

In Malaysia, the "appraisal" is not explicitly described in the LAA, but it is known as the "assessor." If a reappraisal occurs, such as a case in Purworejo and Wonosobo Regencies regarding the determination of the location for the construction of the Bener Dam, according to Article 40A The Act 486, LAA states that:

"Where the objection before the Court is in regard to the amount of the compensation, the Court shall appoint two assessors (one of whom shall be the valuation officer employed by the Government) for the purpose of aiding the Judge in determining the objection and in arriving at a fair and reasonable amount of compensation"

The process that is carried out is through an objection by submitting it to the Court. Furthermore, the Court will appoint an assessor to reassess the land. In the event of a difference by the assessor in assessing then according to 40D Paragraph (1) and (2) The Act 486, Land Acquisition Act 1960 As of 1 January 2015, namely:

In a case before the Court as to the amount of compensation or as to the amount of any of its items the amount of compensation to be awarded shall be the amount decided upon by the two assessors.(2) Where the assessors have each arrived at a decision which differs from each other then the Judge, having regard to the opinion of each assessor, shall elect to concur with the decision of one of the assessors and the amount of compensation to be awarded shall be the amount decided upon by that assessor.

Assessors differ from each other, so the jury, taking into account each assessor's opinion, must choose to approve the decision of one of the assessors, and the amount of compensation to be given is the amount decided by that assessor. It should be noted that the Malaysian legal system adheres to a common law system, where all legal products are based on court decisions. Therefore a re-assessment can be carried out in Malaysia and left to the Court to determine the procedure. The following table compares compensation and reappraisal of land acquisition for the public interest between Indonesia and Malaysia: 
Table 1: Differences in Compensation and Reappraisal of Land Acquisition for the Public Interest between Indonesia and Malaysia

\begin{tabular}{|c|c|c|}
\hline Comparison & Indonesia & Malaysia \\
\hline Legal basis & $\begin{array}{l}\text { Law Number } 2 \text { of } 2012 \text { concerning Land Acquisition for the } \\
\text { Implementation of Development in the Public Interest of } \\
\text { Indonesia in conjunction with Law Number } 11 \text { of } 2020 \\
\text { concerning Job Creation Chapter VIII }\end{array}$ & $\begin{array}{l}\text { The Act 486, Land Acquisition Act } 1960 \text { As at } 1 \text { January } 2015 \\
\text { Malaysia }\end{array}$ \\
\hline Compensation & $\begin{array}{l}\text { 1. Civil Law System } \\
\text { 2. Compensation is a reasonable and fair compensation to } \\
\text { entitled parties in the land acquisition process } \\
\text { 3. a. land; b. space above ground and underground; c. } \\
\text { buildings; d. plants; e. objects related to land; or f. other } \\
\text { assessable losses. } \\
\text { 4. There is compensation for remaining land but it still has } \\
\text { to be considered. }\end{array}$ & $\begin{array}{l}\text { 1. Common Law System } \\
\text { 2. There is no definition of compensation or compensation } \\
\text { 3. a. Size, shape, condition and location of the land; } b \text {. land } \\
\text { use; c. land development potential (if any); and plants; } d \text {. } \\
\text { objects related to land; or e. other assessable losses. } \\
\text { 4. Identify compensation for the remaining land and other } \\
\text { buildings that can or cannot be moved }\end{array}$ \\
\hline Reappraisal & $\begin{array}{l}\text { Indonesia does not regulate a reappraisal in its law, all that } \\
\text { can be repeated is public consultation, even that is still } \\
\text { within the consultation period and there are objections }\end{array}$ & $\begin{array}{l}\text { Malaysia is familiar with the reappraisal by the "assessor". } \\
\text { This procedure is established through the courts by } \\
\text { appointing an "assessor" of the government and a judge. If } \\
\text { there is a difference, the jury's decision will become the } \\
\text { reference. }\end{array}$ \\
\hline
\end{tabular}

Table 2: Similarities in Compensation and Reappraisal of Land Acquisition for the Public Interest between Indonesia and Malaysia

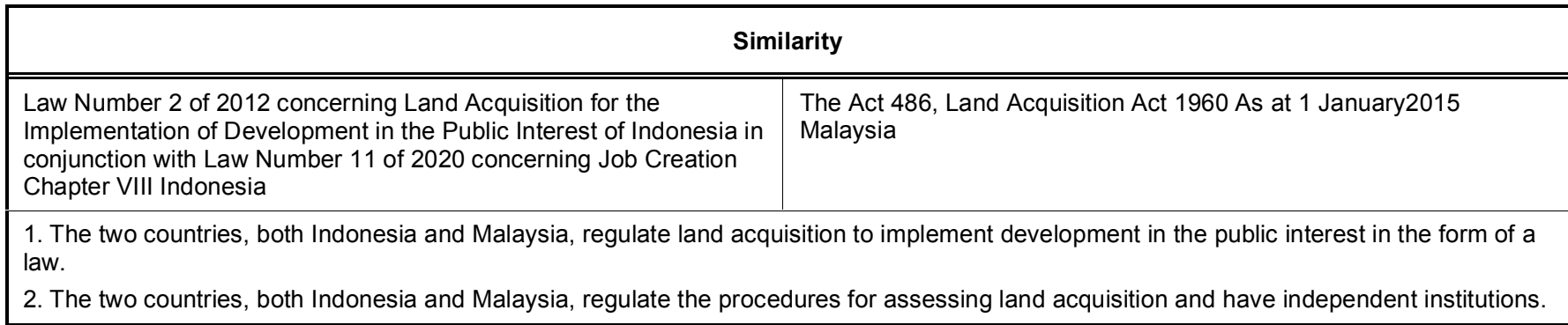

Based on Table 1 above, it can be seen that there are three differences, namely the legal basis used, compensation, and reappraisal: First, The legal basis in Indonesia is regulated in Law Number 2 of 2012 concerning Land Acquisition for the Implementation of Development in the Public Interest of Indonesia in conjunction with Law Number 11 of 2020 concerning Job Copyright Chapter VIII while Malaysia is regulated in Act 486, Land Acquisition Act 1960 As at 1 January 2015 Malaysia. Second, Indonesia's compensation uses a civil law system where compensation can be made if it is regulated in law, while Malaysia adheres to a common law system where compensation can be made if the Court has determined it. Third, In Indonesia, it does not regulate reappraisal in Law Number 2 of 2012 concerning Land Acquisition for the Implementation of Development in the Public Interest, which can be repeated only public consultations, that is still within the consultation period, and there are objections, while in Malaysia there is a re-assessment by the assessor". This procedure is established through the courts by appointing an "assessor" of the government and a judge. If there is a difference, the jury's decision will become the reference.

The similarity of land acquisition for Implementation of Development in the Public Interest relating to compensation and reappraisal, namely; 1 . The two countries, both Indonesia and Malaysia, regulate land acquisition to implement development in the public interest in the form of laws and; 2 . The two countries, both Indonesia and Malaysia, regulate the procedures for assessing land acquisition and have independent institutions.

\section{CONCLUSIONS}

Land acquisition legal arrangements relating to compensation and reappraisal also need to be reviewed in the aspect of legal comparisons between Indonesia and Malaysia. This is to understand better and develop land law in Indonesia, develop an 
understanding of other nations, and contribute to creating a good relationship or atmosphere for the development of international relations and legal harmonization in the formation of supranational law. It can be seen that the two countries, both Indonesia and Malaysia, regulate compensation arrangements in the law. Although both of them depart from different legal systems, where Indonesia is subject to the civil law system and Malaysia is subject to the common law system, both have the same desire to provide benefits to communities whose land is affected by land acquisition public interests. However, what is unfortunate is that Indonesia has not explicitly regulated reappraisal in its law, in the future, it is necessary to consider the pattern of reappraisal carried out by Malaysia because this pattern, according to the author, with the existence of legal vacancies like today, a fast track process is needed to provide justice and legal certainty.

\section{REFERENCES}

Alias, A., \& Daud, M. N. (2015). Payment Of Adequate Compensation For Land Acquisition In Malaysia. Pacific Rim Property Research Journal, 12 (3), 330.

https://doi.org/10.1080/14445921.2006.11104213

Cruz, P. D. (2017). Perbandingan Sistem Hukum Common Law, Civil Law dan Socialist Law. Bandung : Nusa Media.

Dainow, J. (1967). The Civil Law and The Common Law: Some Points of Comparison. The Americal Journal of Comparative Law, 15 (3), 424. https://doi.org/10.2307/838275

Fitri, R. (2018). Hukum Agraria Bidang Pertanahan Setelah Otonomi Daerah. Kanun Jurnal IImu Hukum, 20 (3), 425 https://doi.org/10.24815/kanun.v20i3.11380

Ghimire, S., Tuladhar, A., \& Sharma, S. R. (2017). Governance in Land Acquisition and Compensation for Infrastructure Development. American Journal of Civil Engineering, 5 (3), 169-178. https://doi.org/10.11648/i.ajce.20170503.17

H, R. R. (2019). Menyikapi Globalisasi Hukum Tanah Dengan Kearifan Lokal Media Keadilan. Jurnal IImu Hukum, 10 (2), 221. https://doi.org/10.31764/imk.v10i2.2250

Hadi, S. (2016). Mengkaji Sistem Hukum Indonesia (Kajian Perbandingan Dengan Sistem Hukum Lainnya). DiH Jurnal IImu Hukum, 12 (24), 165-167. https://doi.org/10.30996/dih.v12i24.2244

Hamdi. (2014). Penyelesaian Sengketa Penetapan Ganti Rugi Dalam Pengadaan Tanah Untuk Pembangunan Kepentingan umum (Kajian Terhadap Undang-Undang Nomor 2 Tahun 2012). Jurnal Ius, II (4), 81.

Hamler. (2018). Hukum Tanah Dalam Hak Komunal Masyarakat. Jurnal Ius Civile, 2 (1), 48.

Kaser, M. F.-W. (1990). Romeins Privaatstrecht, N.V.Uitgeverijmaatschappij W.E.J Tjeenk Willink. Amsterdam: Zwolle .

Kumalasari, P. A., \& Sudiarta, I. K. (2020). Pemberian Ganti Rugi Kepada Pemilik Tanah Atas Penggunaan Tanah Perseorangan Tanpa
Pembebasan Oleh Pemerintah. Jurnal Kertha Semaya, 8 (3), 309 310.

Kusumarini, F. R., Silviana, A., \& Triyono. (2016). Penitipan Uang Ganti Kerugian Dalam Pengadaan Tanah (Studi Pengadaan Tanah untuk Pembangunan Proyek Waduk Logung di Kudus). Diponegoro Law Journal, 5 (3), 4.

Maksum, H. (2016). Pelaksanaan Ganti Rugi Pengadaan Tanah Untuk Perluasan Pasar Umum Masbagik Kabupaten Lombok Timur Di Tinjau Dari Undang-Undang Nomor 2 Tahun 2012. Journal IImiah Rinjani, 4, 167-176.

Menski, W. (2015). Perbandingan Hukum Dalam Konteks Global Sistem Eropa, Asia Dan Afrika. Bandung: Nusa Media.

Mohamad, N. A., Sufian, A., \& et al. (2013). Right To Property:The Land Acquisition Act1960 And The Shariah perspective. Jurnal Media Hukum, 20 (1), 81 https://doi.org/10.20885/iustum.vol20.iss1.art5

Mulyadi, M. (2017). Implementasi Kebijakan Pengadaan Tanah Untuk Kepentingan Umum Di Jakarta Utara. Aspirasi, 8 (2), 146.

Mustarin, B. (2020). Ganti Kerugian Pembebasan Tanah Milik Untuk Kepentingan Umum. El-lqtishady, 2 (1), 87-100 https://doi.org/10.24252/el-iqthisadi.v2i1.14041

Noho, M. D. (2019). Politik Hukum Pengaturan Build Operate Transfer (BOT) Di Indonesia: Di Masa Lalu, Saat Ini, Dan Akan Datang. Jurnal Hukum Media Bhakti, 3 (1), 90 https://doi.org/10.32501/jhmb.v3i1.51

Rongiyati, S. (2012). Eksistensi Lembaga Penilai Tanah Dalam Pengadaan Tanah Untuk Kepentingan Umum. Negara Hukum, 3 (1), 7. https://doi.org/10.33476/ajl.v3i1.835

Sari, I. (2017). Hak-Hak Atas Tanah Dalam Sistem Hukum Pertanahan Di Indonesia Menurut Undang-Undang Pokok Agraria (UUPA). Jurnal Mitra Manajemen, 9 (1), 15-16.

Simaremare, S. P., \& Noho, M. D. (2021). Disharmonized the Regulation of Biological Resources and its Ecosystem in Indonesia. International Journal of Criminology and Sociology, 10, 336.

Siregar, M. A., \& Koto, Z. (2015). Hukum Agraria Atas Keberadaan Bangunan Pada Ruang Atas Tanah. Jurnal Nuansa Kenotariatan, 1 (1), 12. https://doi.org/10.31479/ink.v1i1.62

Soekanto, S. (1989). Perbandingan hukum. Bandung: Melati

Soemitro, R. H. (1990). Metodologi Penelitian Hukum dan Jurimetri. Jakarta: Ghalia Indonesia.

Subekti, R. (2016). Kebijakan Pemberian Ganti Kerugian dalam Pengadaan Tanah bagi Pembangunan untuk Kepentingan Umum. Yustisia, 5 (2) 381-382. https://doi.org/10.20961/yustisia.v5i2.8754

Suntoro, A. (2019). Penilaian Ganti Kerugian Dalam Pengadaan Tanah Untukkepentingan Umum: Perspektif Ham. Jurnal Agraria dan Pertanahan, 5 (1), 22. https://doi.org/10.31292/jb.v5i1.316

Tagliarino, N. (2017). The Status of National Legal Frameworks for Valuing Compensation for Expropriated Land: An Analysis of Whether National Laws in 50 Countries/Regions across Asia, Africa, and Latin America Comply with International Standards on Compensation Valuation. Land, 6 (2), 1-29. https://doi.org/10.3390/land6020037

Tuna, T. (2014). Pemberian Ganti Rugi Atas Pengadaan Tanah Untuk Kepentingan Umum. Lex Administratum, I/ (3), 104.

Vikram, M. A., \& Murali, K. (2016). A Critical Review On Land Acquisition And Valuation Process Across The World. IOSR Journal of Mechanical and Civil Engineering, 12 (5), 9-14.

Zakie, M. (2011). Pengadaan Tanah Untuk Kepentingan Umum (Perbandingan antara Malaysia dan Indonesia). Jurnal Hukum, 18 (Edisi Khusus), 204.

https://doi.org/10.6000/1929-4409.2021.10.103

(C) 2021 Sari et al.; Licensee Lifescience Global.

This is an open access article licensed under the terms of the Creative Commons Attribution Non-Commercial License (http://creativecommons.org/licenses/by-nc/3.0/) which permits unrestricted, non-commercial use, distribution and reproduction in any medium, provided the work is properly cited. 